\title{
Beta-methyldigoxin の体内動態
}

\author{
中 島 創* 堤 喜美子* \\ 橋 口 正 行* 海老原 昭 夫*
}

（受付：1988年 12 月 19 日）(特別掲載)

\section{Pharmacokinetics of Beta-methyldigoxin}

Hajime NAKASHIMA* Kimiko TSUTSUMI*

Masayuki HASHIGUCHI* and Akio EBIHARA*

\begin{abstract}
* Department of Clinical Pharmacology, Medical College of Oita, 1-1506, Idaigaoka, Hazama-cho, Oita-gun, Oita-ken 879-56, Japan
\end{abstract}

\begin{abstract}
Beta-methyldigoxin ( $\beta-\mathrm{MD})$ is a cardiac glycoside widely used to treat heart failure and arrhythmia but its pharmacokinetics is not well known. Pharmacokinetic characteristics of $\beta$-MD were studied in five healthy volunteers. After a single oral dose of $\beta$-MD $(0.2 \mathrm{mg})$, the serum glycoside concentrations and urinary glycoside excretions were measured over seven days. The concentrations of $\beta$-MD and its metabolites in serum and urine were determined by high performance liquid chromatography-fluorescence polarization immunoassay method.
\end{abstract}

$\beta$-MD appeared in serum $15 \mathrm{~min}$ after administration and reached the peak serum concentration $(1.88 \pm 0.71 \mathrm{ng} / \mathrm{ml})$ at $0.70 \pm 0.33 \mathrm{hr}$. Elimination half-life, volume of distribution, and renal clearance were found to be $46.5 \pm 14.1 \mathrm{hr}, 9.5 \pm 2.4 \mathrm{l} / \mathrm{kg}$, and $46.0 \pm 14.3 \mathrm{ml} / \mathrm{min}$, respectively. These kinetic parameters were different from data reported previously. Digoxin was the only metabolite observed in serum and its peak concentration was $0.31 \pm$ $0.07 \mathrm{ng} / \mathrm{ml}$ at $1.10 \pm 0.34 \mathrm{hr}$. The percentages of the $\beta$-MD dose renally excreted by $156 \mathrm{hr}$ as $\beta-\mathrm{MD}$, digoxin, digoxigenin bisdigitoxoside, digoxigenin monodigitoxoside, and digoxigenin were $29.55,23.42,1.28,0.36$, and $0.50 \%$, respectively. From serum concentration-time curves, the presence of enterohepatic circulation of $\beta$-MD was suggested.

Key words : $\beta$-methyldigoxin, pharmacokinetics, high performance liquid chromatography, fluorescence polarization immunoassay

\section{緒 言}

Beta-methyldigoxin ( $\beta-\mathrm{MD})$ は digoxin (D 3)の

* 大分医科大学臨床薬理

T879-56 大分県大分郡挾間町医大ケ丘 1-1506
消化管からの吸収を改善する目的で糖末端の 4 位 をメチル化した強心配糖体である. $\beta$-MD は体 内で代謝されて D 3, digoxigenin bisdigitoxoside (D 2), digoxigenin monodigitoxoside (D 1), digoxigenin (D 0) となる. 吸収率は D 3 が 50〜 
$80 \%$ である ${ }^{1 \sim 3)}$ のに対し， $\beta-\mathrm{MD}$ は 80〜 $100 \%{ }^{4 \sim 8)}$ と大きいが，両薬物の心臟住対する薬理作用はほ ぼ等しいといわれている ${ }^{9 \sim 11)}$. 現在 $\beta$-MD の血中 濃度はジゴキシン測定用キットを用い，ラジオイ ムノアッセイ, 螢光偏光イムノアッセイ (FPIA), エンザイムイムノアッセイなどによって測定され ている. これらの抗体は $\beta-M D$ と高い交差反応 性をむつばかりでなく D 3 以外の代謝物とも高 い交差反応性をむつために ${ }^{12 \sim 15)}$ ，測定された $\beta$ $\mathrm{MD}$ の濃度は D 3 およびその他の代謝物を含ん だものとなる. 過去 $\beta$-MD の薬物動態について 多くの報告がなされてきたが， $\beta$-MD とその代謝 物を分離して検討した報告は少ない。われわれは 高速液体クロマトグラフィー (HPLC) と FPIA を用い，血清中および尿中の $\beta-M D$ とその代謝 物の分離定量法を確立し, 第 2 回国際薬物動態学 会において報告した．今回ての方法を用い， $\beta$ MD $0.2 \mathrm{mg}$ を 1 回経口投与したのちの血清中お よび尿中の $\beta-\mathrm{MD}$ とその代謝物を分離定量し体 内動態について榆討を行った.

\section{対象および方法}

\section{1. 対 象}

本試験の目的，方法および予想される副作用等 について十分説明した上で同意を得た健常成人志 願者 5 名（男性 4 名，女性 1 名）を対象之した. 被験者の年齢は 27〜30 歳（平均 29歳）, 体重は $63.0 \sim 74.0 \mathrm{~kg}$ (平均 $67.4 \mathrm{~kg}$ ) であり (Tab. 1), 被験者は身体的所見, 血液学的検査, 血液生化学 的検査, 心電図等で異常は認められなかった。

\section{2. 試験薬剤および試験方法}

Tab. 1 被験者の背景

\begin{tabular}{cccrc}
\hline $\begin{array}{c}\text { 被験者 } \\
\text { No. }\end{array}$ & 性別 & $\begin{array}{r}\text { 年齢 } \\
\text { (歳) }\end{array}$ & $\begin{array}{r}\text { 身長 } \\
(\mathrm{cm})\end{array}$ & $\begin{array}{r}\text { 体重 } \\
(\mathrm{kg})\end{array}$ \\
\hline 1 & $\mathrm{~F}$ & 30 & 161.5 & 65.0 \\
2 & $\mathrm{M}$ & 30 & 167.5 & 65.0 \\
3 & $\mathrm{M}$ & 30 & 167.5 & 74.0 \\
4 & $\mathrm{M}$ & 27 & 174.0 & 70.0 \\
5 & $\mathrm{M}$ & 28 & 166.0 & 63.0 \\
\hline Mean & & 29.0 & 167.3 & 67.4 \\
$\pm \mathrm{SD}$ & & 1.4 & 4.5 & 4.5 \\
\hline
\end{tabular}

被験者は試験前日夜 10 時より絶食とし, 早朝 $\beta$-MD（ラニラピッド®） $0.2 \mathrm{mg}$ を水 $150 \mathrm{ml}$ と ともに服用した。採血は服用前および服用後 5 , $10,15,30,45,60,75,90,120$ 分, $3,4,6$, $8,12,16,20,24,30,48,72,96,120,144$ 時間に行い，被験者 No. 1, 2 亿ついてはこのほ かに 36, 60，84，108 時間に屯採血を行った。 血液は遠心分離 $\left(3,000 \mathrm{rpm}, 4^{\circ} \mathrm{C}, 10\right.$ 分) 後, 血清を濃度測定までー $20^{\circ} \mathrm{C}$ で保存した。採尿は服 用前および服用後 $0 \sim 8,8 \sim 16,16 \sim 24,24 \sim$ $36,36 \sim 60,60 \sim 84,84 \sim 108,108 \sim 132,132 \sim$ 156 時間に行い, 被験者 No. 1, 2 については服用 後 $0 \sim 8,8 \sim 16,16 \sim 24,24 \sim 48,48 \sim 72,72 \sim$ 96，96〜144 洔間に行った，尿量を正確に測定 後, その一部を濃度測定まで $-20^{\circ} \mathrm{C}$ で保存した。

\section{3. 測定方法}

血清 $1 \mathrm{ml}$ を Chem Elut ${ }^{\mathrm{TM}}$ column (Analytichem International, USA) 飞添加後, dichloromethane $20 \mathrm{ml}$ で抽出した. 尿の場合は $5 \mathrm{ml}$ 添加し, dichloromethane $30 \mathrm{ml}$ で抽出した. 抽出 液は窒素ガス下で蒸発乾固後, 溶媒 (n-heptaneisopropylalcohol- $\left.\mathrm{H}_{2} \mathrm{O}, 69: 30: 1\right) 200 \mu 1$ で再構 成し， $100 \mu 1$ を HPLC に注入した. HPLC の条 件は, カラム: Wakopak Lichrosorb Si-60 (5 $\mu \mathrm{m}$, $15 \mathrm{~cm} \times 4.6 \mathrm{~mm} \mathrm{ID)}$, 移動相: $\mathrm{n}$-heptane-isopropylalcohol-dichloromethane- $\mathrm{H}_{2} \mathrm{O}$ (69:20:10:1), 流速: $1.5 \mathrm{ml} / \mathrm{min}$ とした. HPLC で分離した $\beta$ $\mathrm{MD}$ とその代謝物は，あらかじめ $1 \mu \mathrm{g} / \mathrm{ml}$ の標準 液を用いて決定した保持時間に応じて分取し，お のおのの分画を窒素ガス下で蒸発乾固した，得ら れた残渣は，ブランク血漿をTDx Digoxin Assay kit（ダイナボット）中の除蛋白液を用いて除蛋白 した溶液 $0.6 \mathrm{ml}$ で再構成後, TDx Digoxin II Assay により測定した. $\beta$-MD とその代謝物の濃 度は, 既知の濃度のコントロール血清を上記の方 法で測定後, おのおのについての検量線を作成し て求めた.

\section{4. 薬物動態解析}

血清中の $\beta-\mathrm{MD}$ の薬物動態は, 山岡らのプ ログラム, Automated Pharmacokinetic Analysis System (APAS) ${ }^{16)}$ を用い 1 次吸収過程を含む 2 
コンパートメントモデルに当てはめて解析した. 定常状態での分布容量 $(\mathrm{Vdss} / \mathrm{F})$ は, $[\mathrm{Vdss} / \mathrm{F}]=$ $[\mathrm{Vc} / \mathrm{F}] \cdot\left(1+\mathrm{K}_{12} / \mathrm{K}_{21}\right)$ の式を用いて求めた. こと で $\mathrm{F}$ は吸収率, $\mathrm{Vc} / \mathrm{F}$ は中枢コンパートメントの 分布容量, $\mathrm{K}_{12}$ および $\mathrm{K}_{21}$ は中枢コンパートメ ントと末梢コンパートメント間における $\beta-M D$ の 1 次の移行速度定数を表す. また $\beta-M D$ の腎 クリアランスは, 各採尿時間に㹸ける尿量, 尿中 の $\beta$-MD の濃度および血清中の $\beta$ - MD の濃度か ら求めた。得られた成績は Mean $\pm \mathrm{SD}$ で表した。

\section{結 果}

\section{1. 血清中および尿中の $\beta$-MD とその代謝物 の時間的推移}

$\beta$-MD と D 3 の血清中濃度の時間的推移を Fig. 1 飞示した. $\beta$-MD は服用後約 15 分で血 清中に出現し， $0.70 \pm 0.33$ 時間で最高血清中濃 度 $\left(\mathrm{C}_{\max }\right)$ に達した. $\mathrm{C}_{\max }$ は平均 $1.88 \mathrm{ng} / \mathrm{ml}$ で あったが, 1.07 から $2.99 \mathrm{ng} / \mathrm{ml}$ と個人間でばら つきが見られた。 $\beta-M D$ は $\mathrm{C}_{\text {max }}$ 到達後血清中よ り急速に消失し， 6 時間後には $\mathrm{C}_{\max }$ の約 $13 \%$ となった．その後は徐々に血清中から消失し，被 験者 No. 3, 4, 5 は服用後 72 時間, 被験者 No. 1 は 108 時間, 被験者 No. 2 は 144 時間まで血 清中濃度が測定可能であった，被験者 1 人 1 人に ついて $\beta$-MD の血清中濃度-時間曲線をみた場 合, 5 名中 3 名で服用後 6 時間から 8 時間にかけ

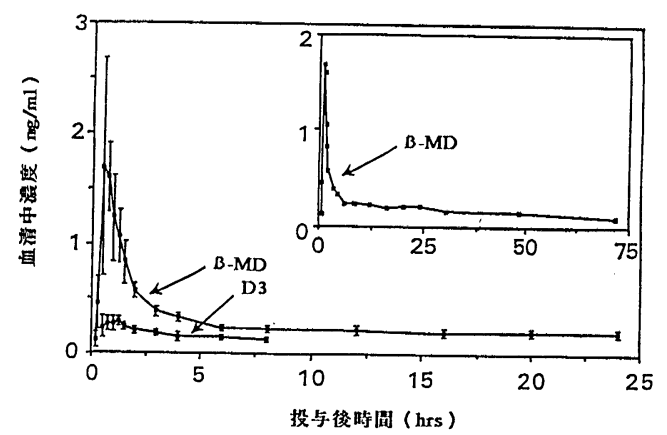

Fig. $1 \beta$-MD および D 3 の血清中濃度-時間曲 線 $(n=5$, Mean $\pm \mathrm{SD})$.

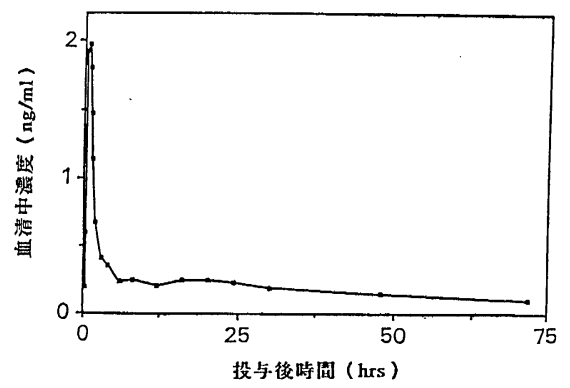

Fig. 2 被験者 (No.5) の血清中 $\beta$ - MD 濃度一時 間曲線。

て濃度の再上昇がみられ，また 5 名中 4 名に 8 時 間から 20 時間にかけて濃度の再上昇がみられた。 てのうち濃度の再上昇が 2 回みられたのは 2 名で あった. Fig. 2 亿濃度の再上昇が 2 回みられた被 験者 No. 5 の血清中濃度-時間曲線を示した. D 3

Tab. $2 \beta$-MD およびその代謝物の尿中排泄率（\%)

\begin{tabular}{lrlllrrr}
\hline 時間 (hr) & 被験者 & D 0 & D 1 & D 2 & D 3 & $\beta$-MD & 総排泄率 \\
\hline \multirow{5}{*}{$0-24$} & No. 1 & 0.26 & 0.13 & 0.61 & 11.71 & 11.19 & 23.89 \\
& 2 & 0.73 & 0.20 & 0.93 & 4.38 & 4.92 & 11.15 \\
& 3 & 0.23 & 0.13 & 0.35 & 7.89 & 16.57 & 25.17 \\
& 4 & 0.44 & 0.20 & 0.81 & 6.71 & 9.99 & 18.16 \\
& 5 & 0.18 & 0.13 & 0.40 & 7.15 & 14.69 & 22.55 \\
\hline & Mean & 0.37 & 0.16 & 0.62 & 7.57 & 11.47 & 20.19 \\
& \pm SD & 0.23 & 0.04 & 0.25 & 2.66 & 4.52 & 5.70 \\
\hline $0-144$ & No. 1 & 0.55 & 0.35 & 1.66 & 41.60 & 27.41 & 71.56 \\
& 2 & 1.05 & 0.45 & 2.11 & 21.11 & 17.05 & 41.77 \\
\hline $0-156$ & 3 & 0.47 & 0.33 & 0.94 & 25.83 & 36.73 & 64.30 \\
& 4 & 0.71 & 0.48 & 1.96 & 22.71 & 21.59 & 47.44 \\
& 5 & 0.33 & 0.26 & 0.94 & 21.72 & 30.32 & 53.58 \\
\hline
\end{tabular}


の血清中への出現は $\beta$-MD より少し遅く, 服用 後約 30 分であった. D 3 の $\mathrm{C}_{\max }$ は $0.31 \pm 0.07$ $\mathrm{ng} / \mathrm{ml}$ で，また最高血清中濃度到達時間（ $\mathrm{t}_{\text {max }}$ ) は $1.10 \pm 0.34$ 時間であった. D 3 の血清中濃度 は, 被験者 No. 1 と No. 2 は 144 時間まで, 被 験者 No. 3 と No. 4 は 48 時間まで測定可能で あった。しかし被験者 No. 5 は 8 時間までしか測 定できなかった。 D 3 以外の代謝物の血清中への 出現は，1名の被験者 (No. 4) で服用後 0.5 時間 に D0 が $0.022 \mathrm{ng} / \mathrm{ml}, \mathrm{D} 1$ が $0.074 \mathrm{ng} / \mathrm{ml}, 0.75$ 時間に D0 が $0.011 \mathrm{ng} / \mathrm{ml}$, D 2 が $0.039 \mathrm{ng} / \mathrm{ml}$, さらに $1,1.25,1.5$ 時間に D 2 がそれぞれ 0.02， 0.104，0.095 ng/ml 認められた. しかしその他の 被験者では検出されなかった。 $\beta$-MD とその代謝 物 (D 3，D 2, D 1，D 0) の尿中への排泄は，服 用後 24 時間でそれぞれ投与量の $11.47 ， 7.57$, $0.62 ， 0.16 ， 0.37 \%$ であり, 総排泄量は投与量の $20.19 \%$ であった. また服用後 156 時間（144 時
間）までにはそれぞれ 29.55 (22.23)，23.42 (31.35), 1.28(1.88), $0.36(0.40), 0.50(0.80) \%$ が排泄され，総排泄量は投与量の約 55 (56)\% で あった (Tab. 2).

\section{2. 薬物動態}

及-MD $0.2 \mathrm{mg}$ を経口投与したときの血清中濃 度を 2 コンパートメントモデルを用いて解析し， その薬物動態值を Tab. 3 亿示した. $\alpha$ 相および $\beta$ 相における除去半減期 $\left(\mathrm{t}_{1 / 2 \alpha}, \mathrm{t}_{1 / 2 \beta}\right)$ はそれぞれ $0.45 \pm 0.07$ 時間， $46.51 \pm 14.08$ 時間であった. このうち $\beta$ 相における $\mathrm{t}_{1 / 2 \beta}$ は $27.42 \sim 66.08$ 時間と個人間で大きなばらつきがみられた。1 次 の吸収速度定数 $\left(\mathrm{K}_{\mathrm{a}}\right)$ は $5.60 \pm 7.81 \mathrm{hr}^{-1}$ であっ たが，乙れは被験者 No. 3 が高值を示しているた めで，ての 1 名を除いたときの $\mathrm{K}_{\mathrm{a}}$ は $2.37 \pm$ $0.87 \mathrm{hr}^{-1}$ であった. 1 次の除去速度定数 $\left(\mathrm{K}_{\mathrm{e}}\right)$, 定常状態での分布容量 (Vdss/F) および中枢コン パートメントの分布容量 $(\mathrm{Vc} / \mathrm{F})$ はそれぞれ 0.17

Tab. $3 \beta-\mathrm{MD}$ の薬物動態值

\begin{tabular}{rcccccccccccc}
\hline $\begin{array}{c}\text { 被験者 } \\
\text { No. }\end{array}$ & $\begin{array}{c}\mathrm{t}_{\max } \\
(\mathrm{hr})\end{array}$ & $\begin{array}{c}\mathrm{C}_{\max } \\
(\mathrm{ng} / \mathrm{ml})\end{array}$ & $\begin{array}{c}\mathrm{t}_{1 / 2 \alpha} \\
(\mathrm{hr})\end{array}$ & $\begin{array}{c}\mathrm{t}_{1 / 2 \beta} \\
(\mathrm{hr})\end{array}$ & $\begin{array}{c}\mathrm{K}_{\mathrm{s}} \\
\left(\mathrm{hr}^{-1}\right)\end{array}$ & $\begin{array}{c}\mathrm{K}_{\mathrm{e}} \\
\left(\mathrm{hr}^{-1}\right)\end{array}$ & $\begin{array}{c}\mathrm{K}_{12} \\
\left(\mathrm{hr}^{-1}\right)\end{array}$ & $\begin{array}{c}\mathrm{K}_{21} \\
\left(\mathrm{hr}^{-1}\right)\end{array}$ & $\begin{array}{r}\mathrm{CL}_{\text {tot }} / \mathrm{F} \\
(l / \mathrm{hr})\end{array}$ & $\begin{array}{r}\mathrm{Vd}_{\mathrm{ss}} / \mathrm{F} \\
(l / \mathrm{kg})\end{array}$ & $\begin{array}{c}\mathrm{V}_{\mathrm{c}} / \mathrm{F} \\
(l / \mathrm{kg})\end{array}$ & $\begin{array}{c}\mathrm{AUCC} / \mathrm{F} \\
(\mathrm{ng} \cdot \mathrm{hr} / \mathrm{ml})\end{array}$ \\
\hline 1 & 0.50 & 1.76 & 0.46 & 41.47 & 3.62 & 0.13 & 1.20 & 0.19 & 9.97 & 8.49 & 1.17 & 20.06 \\
2 & 1.25 & 1.07 & 0.55 & 66.08 & 1.70 & 0.08 & 1.02 & 0.16 & 9.05 & 12.53 & 1.72 & 21.91 \\
3 & 0.50 & 2.99 & 0.35 & 27.42 & 18.54 & 0.27 & 1.56 & 0.19 & 13.86 & 6.52 & 0.71 & 14.43 \\
4 & 0.50 & 1.57 & 0.46 & 50.97 & 1.88 & 0.17 & 1.23 & 0.12 & 11.81 & 11.16 & 1.02 & 16.93 \\
5 & 0.75 & 1.99 & 0.42 & 46.62 & 2.26 & 0.19 & 1.34 & 0.13 & 9.01 & 8.57 & 0.74 & 22.20 \\
\hline Mean & 0.70 & 1.88 & 0.45 & 46.51 & 5.60 & 0.17 & 1.27 & 0.16 & 10.74 & 9.45 & 1.07 & 19.11 \\
$\pm \mathrm{SD}$ & 0.33 & 0.71 & 0.07 & 14.08 & 7.28 & 0.07 & 0.20 & 0.03 & 2.08 & 2.38 & 0.41 & 3.35 \\
\hline
\end{tabular}

$t_{\max }$ : 最高血清中濃度到達時間, $\mathrm{C}_{\max }$ : 最高血清中濃度, $\mathrm{t}_{1 / 2 \alpha}: \alpha$ 相の除去半減期, $\mathrm{t}_{1 / 2 \beta}: \beta$ 相の除去半減期,

$\mathrm{K}_{\mathrm{a}}$ : 1 次の吸収速度定数, $\mathrm{K}_{\mathrm{e}}$ : 1 次の除去速度定数, $\mathrm{K}_{12}$ : 中枢コンパートメントから末梢コンパートメントヘ の 1 次の移行速度定数, $\mathrm{K}_{21}$ : 末梢コンパートメントから中枢コンパートメントへの 1 次の移行速度定数, $\mathrm{CL}_{\text {tot }} / \mathrm{F}$ : 総クリアランス, $\mathrm{Vd}_{\mathrm{ss}} / \mathrm{F}$ : 定常状態での分布容量, $\mathrm{V}_{\mathrm{c}} / \mathrm{F}:$ 体循環コンパートメントの分布容量, $\mathrm{AUC} / \mathrm{F}$ : 血清中濃度-時間曲線下面積, F : 吸収率.

Tab. 4 各蓄尿時間における $\beta$-MD の腎クリアランス $(\mathrm{ml} / \mathrm{min})$

\begin{tabular}{rrrrrrrr}
\hline 蓄尿時間 $(\mathrm{hr})$ & $0-8$ & $8-16$ & $16-24$ & $24-48$ & $48-72$ & $72-96$ & $96-144$ \\
\hline 被験者 No. 1 & 70.3 & 35.5 & 58.7 & 46.5 & 46.0 & 33.3 & 47.2 \\
2 & 49.7 & 15.9 & 15.8 & 50.4 & 45.9 & 36.2 & 31.2 \\
\hline 蓄尿時間 (hr) & $0-8$ & $8-16$ & $16-24$ & $24-36$ & $36-60$ & $60-84$ \\
\hline 被験者 No. 3 & 133.8 & 54.9 & 74.3 & 85.9 & 55.5 & 50.7 \\
4 & 91.7 & 45.3 & 48.4 & 43.6 & 39.0 & 49.5 & 42.5 \\
\hline 5 & 108.7 & 44.7 & 51.7 & 51.3 & 42.2 & \\
\hline
\end{tabular}


$\pm 0.07 \mathrm{hr}^{-1}, 9.45 \pm 2.38 \mathrm{l} / \mathrm{kg}, 1.07 \pm 0.41 \mathrm{l} / \mathrm{kg}$ で あり，さらに総クリアランス $\left(\mathrm{CL}_{\text {tot }} / \mathrm{F}\right)$ は 10.74 $\pm 2.08 \mathrm{l} / \mathrm{kg}$ であった. また血清中濃度一時間曲線 下面積 $\left(A U C^{0 \sim \infty} / \mathrm{F}\right)$ は $19.11 \pm 3.35 \mathrm{ng} \cdot \mathrm{hr} / \mathrm{ml}$ で あった．各時間における $\beta-\mathrm{MD}$ の腎クリアラン スは Tab. 4 に示した. 最初の 8 時間における腎 クリアランスは被験者間でかなりのばらつきが 見られたが，8時間以降はほぼ一定しており， $46.01 \pm 14.33 \mathrm{ml} / \mathrm{min}$ であった.

\section{考 察}

健常成人 5 名に $\beta$-MD $0.2 \mathrm{mg}$ を 1 回経口投与 し，服用後の血清中および尿中の $\beta-M D$ とその 代謝物を分離定量しその体内動態について調べ た. $\beta$-MD は服用後約 15 分で血清中に出現し, $\mathrm{t}_{\max }$ は $42.0 \pm 19.8$ 分であった. これは $\mathrm{t}_{\max }$ が $50 \pm 9$ 分とする Hinderling らの報告 ${ }^{8}$ とほぼ等 しいものであった. $\beta$ 相における $\mathrm{t}_{1 / 2 \beta}$ は 46.5 時間であり，D 3 を投与したときの $\mathrm{t}_{1 / 2 \beta} \quad 26 〜 44$ 時間17 20) より延長していた. Vdss/F は 9.45士 $2.38 \mathrm{l} / \mathrm{kg}$ であり，てれは過去報告されている D3 の $6.7 \pm 1.4 l / \mathrm{kg}^{21)}$ に比べ明らかに大きかった。

Kuhlmann ら ${ }^{22)}$ はイヌにおいて $\beta$-MD および D 3 の組織への分布を検討し, D 3 に比べ $\beta$-MD はとくに中枢神経系に多く分布すると報告してい る. これらのととより $\beta$ - $\mathrm{MD}$ と $\mathrm{D} 3$ の $\mathrm{Vdss} / \mathrm{F}$ の差は末梢コンパートメントにおける分布の違い によるものと考えられた.

血清中の D 3 以外の代謝物は，1名でわずか に検出されたが他の被験者からは検出されず，ま た 156 時間までの D 2, D 1, D 0 の尿中排泄量む 全尿中排泄量の $2.30,0.65 ， 0.91 \%$ とわずかで あった.したがって体内においては D3 からそれ 以降の代謝物（D2，D1，D0）には代謝されにく いと考えられた.さらに被験者 1 人 1 人について $\beta-\mathrm{MD}$ の血清中濃度一時間曲線を検討した場合， 4 名の被験者で 0〜20 時間のあいだに濃度の再上 昇が $1 \sim 2$ 回みられた. ての再上昇が食事よりや や遅れて出現しているととより， $\beta-\mathrm{MD}$ はD 3 と 同様に腸肝循環が存在すること ${ }^{23)}$ が示唆された.

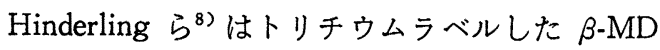

を服用させ，得られた血清中および尿中の $\beta-\mathrm{MD}$ とその代謝物を薄層クロマトグラフィーを用いて 分離している. 彼らの報告では， $\beta$ - MD を服用後 144 時間までの尿中総排泄量は投与量の $57.7 \%$ であり，また尿中総放射活性に対する $\beta$ - MD 之 D 3 の割合は，それぞれ 40.6，45.2\%であった. Rietbrock ら5) もほぼ同様の結果を報告している. われわれの結果であ 156 時間までに投与量の約 $55 \%$ が尿中に排泄され， 5 名中 3 名は， $\beta$-MD に 比べ D 3 のほうが多く排泄されていた. $\beta$-MD の腎クリアランスは $46.0 \pm 14.3 \mathrm{ml} / \mathrm{min}$ であった

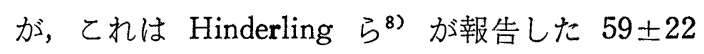
$\mathrm{ml} / \mathrm{min}$ とほぼ同じであり, D 3 の腎クリアラン ス $100 \sim 150 \mathrm{ml} / \mathrm{min}^{19,24,25)}$ に比べ明らかに小さか った. Marinow ら ${ }^{26)}$ は $\beta$-MD の腎クリ广ランス を $105 \mathrm{ml} / \mathrm{min}$ と報告しているが，乙れは $\beta-\mathrm{MD}$ とD 3 を分離しておらず，両者をあわせて評価し ているためと考えられた.

今回の研究において分離定量して得られた $\beta$ $M D$ の薬物動態は，過去報告されている D3 の薬 物動態とは異なるものであった， $\beta$-MD を内服し た場合， $\beta$-MD の一部は体内で代謝されて D 3 に なるために血清中には薬物動態の異なる $\beta-\mathrm{MD}$ と D 3 が存在するととになる.したがって $\beta-M D$ の体内動態を検討する上では $\beta-\mathrm{MD}$ とその代謝 物を分離定量して検討することが必要であると考 えられた．今回は健常成人について $\beta$-MD の体内 動態を検討したが，肝機能障害や腎機能障害が存 在する場合は血清中の $\beta-\mathrm{MD}$ と D 3 の割合やそ れぞれの濃度が異なってくるととが考えられる。

Rameis ら ${ }^{27)}$ 屯肝硬変の患者之健常人に $\beta$-MD を内服させ血清中の $\beta-\mathrm{MD}$ と D 3 の濃度を検討 した結果，肝硬変の患者では $\beta-\mathrm{MD}$ の割合が有 意に高くなるととを報告している， $\beta$-MD の安全 で有効な使用のために今後てれらの疾患における $\beta$-MD の体内動態についても検討していく必要が あると思われた.

本研究を行うに当たり有益なご助言をいただいた九 州大学医学部附属病院薬剂部の樋口駿先生, 山之内製 薬開発部臨床統計室の方々に深く感謝いたします。 


\section{文 献}

1) Greenblatt, D. J., Duhme, D. W., Koch-Wester, J. et al. : Evaluation of digoxin bioavailability in single-dose studies. N. Engl. J. Med., 289 : 651-654 (1973).

2) Kramer, W. G. and Reuning, R. H. : Use of area under the curve to estimate absolute bioavailability of digoxin. J. Pharm. Sci., $67: 141-142$ (1978).

3) Flasch, H., Asmussen, B. and Heinz, N. : Erhöhte bioverfügbarkeit von digoxin aus kieselsäurematrix-zubereitungen. Arzneim. Forsch./Drug Res., 28 : 326-330 (1978).

4) Beermann, B.: The gastrointestinal uptake of methyldigoxin $-12 \alpha{ }^{3} \mathrm{H}$ in man. Eur. J. Clin. Pharmacol., 5 : 28-33 (1972).

5) Rietbrock, N., Abshagen, U., Bergmann, K. v. et al.: Disposition of $\beta$-methyldigoxin in man. Eur. J. Clin. Pharmacol., 9 : 105-114 (1975).

6) Rietbrock, N., Guggenmos, J., Kuhlmann, J. et al. : Bioavailability and pharmacokinetics of $\beta$ methyldigoxin after multiple oral and intravenous doses. Eur. J. Clin. Pharmacol., 9 : 373379 (1976).

7) Boerner, D., Olcay, A., Schaumann, W. et al. : Absorption of $\beta$-methyl-digoxin determined after a single dose and under steady state condi. tions. Eur. J. Clin. Pharmacol., 9 : 307-314 (1976).

8) Hinderling, P.H., Garrett, E.R. and Wester, R.C.: Pharmacokinetics of $\beta$-methyldigoxin in healthy humans II : Oral studies and bioavailability. J. Pharm. Sci., 66 : 314-325 (1977).

9) Schaumann, W. and Koch, K.: $\beta$-Methyl-digoxin: VI. Tissue distribution, positive inotropic and central action in cats in comparison with other digitalis glycosides. Naunyn-Schmiedeberg's Arch. Pharmacol., 286 : 195-210 (1974).

10) Das, G., Talmers, F.N., Smith, W.S. et al.: Comparison of cardiotropic effects and serum glycoside levels to beta-methyldigoxin and digoxin in man. Clin. Pharmacol. Ther., $19: 105$ (1976).

11) Andersson, K.E., Johansson, B. W., Ledermann, $H$. et al. : The effects of digoxin and $\beta$-methyldigoxin on the heart rate of decompensated patients with atrial fibrillation. Eur. J. Clin. Invest., 7 : 3-6 (1977).

12) Stoll, R. G., Christensen, M. S., Sakmar, E. et al. : The specificity of the digoxin radioimmunoassay procedure. Res. Commun. Chem. Pathol. Pharmacol., 4 : 503-510 (1972).

13）扇谷茂樹, 船木正明, 初田和由ほか: 蛍光偏光免疫 測定法による血中ジゴキシン測定法の特異性とそ の応用に関する研究. 衛生検査, $33: 143-147$ (1983).
14) Goto, M., Suzuki, A., Terashima, T. et al. : Variances in pharmacokinetic parameters due to assay methods for $\beta$-methyldigoxin. J. Pharmacobio-Dyn., 10 : 209-214 (1987).

15) Manchester, E. L., Giesbrecht, E. and Soldin, S. J. : Receptor radioligand system for measuring digoxin activity. Ther. Drug Monit., 9: 6166 (1987).

16) 山岡 清, 谷川原裕介: マイコンによる薬物速度論 入門，南江堂, 東京, pp. 159-178 (1983).

17) Kramer, W. G., Lewis, R.P., Cobb, T.C. et al. : Pharmacokinetics of digoxin: Comparison of a two- and a three-compartment model in man. J. Pharmacokin. Biopharm., 2 : 299-312 (1974).

18) Nyberg, L., Andersson, K. E. and Bertler, A..: Bioabailability of digoxin from tablets. Acta Pharm. Suec., 11 : 459-470 (1974).

19) Koup, J. R., Greenblatt, D. J., Jusko, W. J. et al.: Pharmacokinetics of digoxin in normal subjects after intravenous bolus and infusion doses. J. Pharmacokin. Biopharm., 3 : 181-192 (1975).

20) Ritschel, W. A. : Handbook of Bascic Pharmacokinetics, Drug Intelligence, Inc., Hamilton, IL., p. 325 (1976).

21) Reuning, R.H. and Geraets, D. R.: Digoxin. Evans, W.E., Schentag, J. J., Jusko, W. J. et al. (Ed.s): Applied Pharmacokinetics, Principles of Therapeutic Drug Monitoring, 2 nd ed., Applied Therapeutics, Inc., Spokane, WA., pp. 570-623 (1986).

22) Kuhlmann, J., Rietbrock, N. and Schnieders, B. : Tissue distribution and elimination of digoxin and methyldigoxin after single and multiple doses in dogs. J. Cardiovasc. Pharmacol., 1 : 219234 (1979).

23) Doherty, J.E., Flanigan, W. J., Murphy, M. L. et al.: Tritiated digoxin XIV. Enterohepatic circulation, absorption, and excretion studies in human volunteers. Circulation, 42 : 867-873 (1970).

24) Bloom, Ph. M. and Nelp, W. B.: Relationship of the excretion of tritiated digoxin to renal function. Am. J. Med. Sci., 43 : 133-154 (1966).

25) Sumner, D. J., Russell, A. J. and Whiting, B. : Digoxin Pharmacokinetics: Multicompartmental analysis and its clinical implications. Br. J. Clin. Pharmacol., 3 : 221-229 (1976).

26) Marinow, J., Olcay, A., Schaumann, W. et al.: Serum glycoside concentrations after single or repeated intravenous doses of $\beta$-methyl-digoxin and digoxin. Eur. J. Clin. Pharmacol., 11 :213218 (1977).

27) Rameis, H., Woodcock, B., Bonelli, J. et al. : Changes in metildigoxin pharmacokinetics in cirrhosis of the liver: a comparison with $\beta$ acetyldigoxin. Int. J. Clin. Pharmacol., Ther. Toxicol., 22 : 145-151 (1984). 